\title{
Lipasin/Betatrophin Is Differentially Expressed in Liver and White Adipose Tissue Without Association With Insulin Resistance in Wistar and Goto-Kakizaki Rats
}

\author{
M. CAHOVÁ ${ }^{1 *}$, D. HABART ${ }^{2 *}$, T. OLEJÁR ${ }^{3}$, Z. BERKOVÁ $^{2}$, Z. PAPÁČKOVÁ $^{1}$, \\ H. DAŇKOVÁ ${ }^{1}$, A. LODEREROVA ${ }^{4}$, M. HECZKOVÁ ${ }^{1}$, F. SAUDEK ${ }^{2}$ \\ *These authors contributed equally to this work.
}

${ }^{1}$ Centre for Experimental Medicine, Department of Metabolism and Diabetes, Institute for Clinical and Experimental Medicine, Prague, Czech Republic, ${ }^{2}$ Diabetes Centre, Institute for Clinical and Experimental Medicine, Prague, Czech Republic, ${ }^{3}$ Department of Pathology and Molecular Medicine, Thomayer Hospital, Prague, Czech Republic, ${ }^{4}$ Clinical and Transplant Pathology Department, Institute for Clinical and Experimental Medicine, Prague, Czech Republic

Received March 6, 2016

Accepted August 5, 2016

On-line December 16, 2016

\section{Summary}

Lipasin is a recently identified lipokine expressed predominantly in liver and in adipose tissue. It was linked to insulin resistance in mice and to type 1 and type 2 diabetes (T1D, T2D) in humans. No metabolic studies concerning lipasin were performed yet in rats. Therefore, we used rat model of $\mathrm{T} 2 \mathrm{D}$ and insulin resistance, Goto-Kakizaki (GK) rats, to determine changes of lipasin expression in liver and in white adipose tissue (WAT) over 52 weeks in the relation to glucose tolerance, peripheral tissue insulin sensitivity and adiposity. GK rats were grossly glucose intolerant since the age of 6 weeks and developed peripheral insulin resistance at the age of 20 weeks. Expression of lipasin in the liver did not differ between GK and Wistar rats, declining with age, and it was not related to hepatic triacylglycerol content. In WAT, the lipasin expression was significantly higher in Wistar rats where it correlated positively with adiposity. No such correlation was found in GK rats. In conclusion, lipasin expression was associated neither with a mild age-related insulin resistance (Wistar), nor with severe genetically-based insulin resistance (GK).

\section{Key words}

Lipasin/betatrophin • Insulin resistance • Goto-Kakizaki • Liver • Adipose tissue

\section{Corresponding author}

M. Cahova, OMD CEM, Institute for Clinical and Experimental Medicine, Videnska 1958, 14021 Prague 4, Czech Republic. E-mail: monika.cahova@ikem.cz

\section{Introduction}

Growing evidence suggests that reduction of functional $\beta$-cell mass together with insulin resistance leads to the development of overt type 2 diabetes (Liebowitz et al. 2011). Evidence of a circulating factor inducing $\beta$-cell proliferation in an insulin-resistant state was provided by Flier, who reported markedly increased proliferation rate in isolated pancreatic islets after transplantation under the kidney capsule of insulinresistant mice (IRS1/insulin receptor double $\mathrm{KO}$ and $o b / o b)$ (Flier et al. 2001). Yi et al. (2013) suggested a link between insulin resistance and recently described lipokine lipasin (betatrophin/RIFL/TD26) (Zhang and Abou-Samra 2013, Quagliarini et al. 2012, Ren et al. 2012), by showing a marked increase of lipasin transcription after few weeks of insulin-resistance induced by insulin receptor antagonist S961 in mice (Yi et al. 2013). Under the basal conditions, lipasin was found predominantly expressed in liver and adipose tissue. Ren et al. (2012) found metabolic regulation when 
demonstrated dramatically increased lipasin mRNA expression after refeeding in mice. Yi et al. (2013) observed increased $\beta$-cell proliferation associated with lipasin over-expression and proposed it as the mediator of $\beta$-cell regeneration in mice, hence the new name betatrophin. Similar observation was reported in rats (Chen et al. 2015). However, the claim of lipasin as the important mediator of $\beta$-cell regeneration in mice was later disproved (Gusarova et al. 2014, Kaestner et al. 2014, Yi et al. 2014). Nevertheless, lipasin as a regulatory lipokine (Stephens 2012, Zhang and AbouSamra 2014) remains of a great interest and a number of studies tried to understand its role and its regulation in the metabolic disturbances during the development of insulin-resistance and diabetes in humans. Trebotic et al. (2015) reported increased levels of circulating lipasin in both normal pregnancy and in gestational diabetes. Elevated serum lipasin concentration was found in obesity, T2D and T1D patients (Fu et al. 2014b, Yamada et al. 2015). Tokumoto et al. (2015) suggested that in humans lipasin serum concentrations positively correlated with the duration of T2D and inversely with insulin secretory capacity. Chen et al. (2015) reported positive correlation between serum levels of lipasin and the homeostasis model assessment of insulin resistance index. This group also found inverse correlation between serum levels of lipasin and the quantitative insulinsensitivity check index in newly diagnosed T2D patients. On the other hand, Gomez-Ambrosi et al. (2014) reported reduced serum lipasin concentrations in human obesity and in obesity-associated insulin resistance. Fenzl et al. (2014) found correlation of circulating lipasin with atherogenic lipid profiles in high-risk obesity or type 2 diabetes, but no association with $\beta$-cell function and glucose homeostasis. In summary, while a number of studies support positive association between lipasin plasma levels and insulin-resistance, diabetes and adiposity, conflicting findings remain unresolved. The studies in humans were confined to the protein levels in serum, for practical reasons. Animal models of type 2 diabetes allow discerning the regulation of lipasin in individual tissues. So far, rodent metabolic studies were published only on mice, where an increase of mRNA of lipasin expression in liver and fat were reported in $o b / o b$, $d b / d b$ and in pregnant mice (Yi et al. 2013). No metabolic studies concerning lipasin were performed yet in rats.

Goto-Kakizaki (GK) rats represent a widely used model of T2D. It was established by breeding Wistar rats selected at the upper limit of normal glucose tolerance. In GK rats early glucose intolerance and peripheral tissue insulin resistance develop spontaneously, their beta-cell mass and function gradually deteriorate, and overt hyperglycemia ensue (Portha et al. 2012). Aim of our study was to determine age-related changes in lipasin expression in the liver and white adipose tissue (WAT) over the period of one year and in the relation to the above mentioned characteristics. The data were compared to the Wistar rats as age-related controls.

\section{Methods}

Animals and experimental design

Four weeks old Goto-Kakizaki rats

(GK/MolTac, Aarhus colony) and Wistar Han rats were purchased from Taconic Farms, Inc., Hudson, NY and kept in the IKEM breeding facility in a temperaturecontrolled environment with a $12 \mathrm{~h}$ light/dark cycle. The animals were randomized into 4 subgroups each comprising 6-8 animals and assayed at the age of 6, 20, 40, and 52 weeks. The animals had free access to the standard laboratory chow diet, and to the tap water. All tests including weighing, blood sampling, and glucose tolerance tests were initiated between 8-9 a.m. on random fed animals. Blood glucose concentration was measured by Accu-chek glucometer, insulin concentrations were determined using Rat Insulin kit (Mercodia, Sweden). Adiposity was defined as the wet weight of epididymal fat pads normalized per $100 \mathrm{~g}$ body weight (Sedova et al. 2004). Triacylglycerol content in the liver was determined as described previously (Cahova et al. 2004). All experiments were performed in accordance with the Animal Protection Law of the Czech Republic 311/1997, which is in compliance with the Principles of Laboratory Animal Care (NIH Guide to the Care and Use of Laboratory Animals, $8^{\text {th }}$ edition, 2013) and were approved by the Ethical Committee of IKEM (permission no. 26/2012).

\section{Glucose tolerance test}

Glucose tolerance in 6 weeks old animals was measured by intraperitoneal glucose tolerance test (IPGTT). Fasted rats were administered glucose $3 \mathrm{~g} / \mathrm{kg}$ b.w. intraperitoneally and blood glucose concentration was measured in $30 \mathrm{~min}$ intervals for next $120 \mathrm{~min}$. In older animals (20, 40 and 52 weeks), intravenous glucose tolerance test (IVGTT) was employed. Fasted rats were injected with $20 \%$ glucose into tail vein $(1 \mathrm{~g} / \mathrm{kg}$ b.w.) 
and blood glucose was measured at the $10 \mathrm{~min}$ time intervals up to $60 \mathrm{~min}$.

Determination of muscle and adipose tissue insulin sensitivity in vitro

The procedure was performed as described previously (Cahova et al. 2004). Tissue sensitivity to insulin was measured in vitro by ${ }^{14} \mathrm{C}$-glucose incorporation into lipids (adipose tissue) or glycogen (musculus soleus). Distal parts of epididymal adipose tissue (approx. 150 $\pm 25 \mathrm{mg}$ ) and musculus soleus $(160 \pm 20 \mathrm{mg})$ were rapidly dissected. Soleus muscles were attached to a stainless steel frame in situ at in vivo length. The tissues were incubated $2 \mathrm{~h}$ at Krebs-Ringer bicarbonate buffer with $5 \mathrm{mmol} / \mathrm{l}$ glucose; $0.1 \mathrm{mCi}$ (U- ${ }^{14} \mathrm{C}$ )-glucose/ml (UVVR, Czech Republic) and $2 \%$ (adipose tissue) or $0.5 \%$ (m. soleus) bovine serum albumin, gaseous phase $95 \% \mathrm{O}_{2}$ and $5 \% \mathrm{CO}_{2}$ in the presence $(250 \mathrm{mU} / \mathrm{ml})$ or absence of insulin in incubation medium. All the incubations were carried out at $37^{\circ} \mathrm{C}$ in sealed vials in shaking water bath. Neutral lipids were extracted to chloroform/methanol $(2: 1)$ and the radioactivity was counted by scintillation counting. ${ }^{14} \mathrm{C}$-glucose accumulation into glycogen in soleus was determined after tissue digestion by boiling in $30 \% \mathrm{KOH}$ and precipitation in $96 \%$ ethanol.

\section{Isolation and cultivation of rat pancreatic islets}

Pancreatic islets were isolated using collagenase digestion followed by separation in a discontinuous density gradient, as previously described (Berkova et al. 2005). Briefly, rat pancreata were cannulated through the bile duct and filled with $15 \mathrm{ml}$ of collagenase solution (1 mg/ml) (Sevapharma, Czech Republic). The excised pancreata were incubated for $18 \mathrm{~min}$ at $37^{\circ} \mathrm{C}$ with moderate shaking. Collagenase digestion was stopped by several washing steps with cold Hank's Balanced Salt Solution (supplemented with $1 \%$ fetal bovine serum), and the tissue suspension was filtered through a $500 \mu \mathrm{m}$ mesh. Pancreatic islets were separated using Ficoll (Sigma-Aldrich) discontinuous density gradient yielding in 600-700 purified islets per rat.

\section{Glucose-stimulated insulin secretion (GSIS) test}

Freshly isolated islets from individual animals were divided into three aliquots of 20 islets, pipetted on polyester membranes with $8 \mu \mathrm{m}$ pores (Transwell cell culture inserts, Corning, NY, USA), placed into six well plate and incubated for $18 \mathrm{~h}$ at $5 \% \mathrm{CO}_{2}$ and $37^{\circ} \mathrm{C}$ in
$4 \mathrm{ml}$ of islet culture media (CMRL supplemented with $10 \%$ FBS, 10 mM HEPES, 2 mM Glutamax, $100 \mathrm{U} / \mathrm{ml}$ Penicillin, and $100 \mu \mathrm{g} / \mathrm{ml}$ Streptomycin). The GSIS assay medium consisted of Krebs-Ringer bicarbonate buffers equilibrated with $5 \% \mathrm{CO}_{2}$ at $37^{\circ} \mathrm{C}$, and supplemented with either $3 \mathrm{mM}$ (low) or $22 \mathrm{mM}$ (high) glucose. Throughout the assay care was taken to minimize mechanical stress on the islets. All incubations were carried on at $37^{\circ} \mathrm{C}$ and $5 \% \mathrm{CO}_{2}$, in the volume of $4 \mathrm{ml}$. Islets were equilibrated for $15 \mathrm{~min}$ in low glucose GSIS assay medium. Glucose-stimulated insulin secretion was then tested over $60 \mathrm{~min}$ at three subsequent concentrations of glucose (low, high and again low). After each incubation period, insulin from the vicinity of the islets was gently flushed into the corresponding lower chamber, and mixed medium was sampled. After the assay, albumin was washed from the islets with PBS and islets were collected and lysed using proteinase K, EDTA and SDS. Total DNA content in each assayed islet aliquot was determined using dsDNA specific assay, PicoGreen kit (Invitrogen, USA).

\section{Immunohistochemistry}

Immunohistochemical detection of PCNA (mouse monoclonal, Dako, Denmark) was performed on $4 \mu \mathrm{m}$-thick paraffin sections using a two-step indirect method. After deparaffinization in xylene and rehydration in graded ethanol, endogenous peroxidase was blocked. Primary antibody anti PCNA was applied for $30 \mathrm{~min}$. The antibody was detected by Histofine Simple Stain Rat MAX PO (Nichirei, Japan). Finally visualization was performed with the Dako Liquid DAB+ SubstrateChromogen System (Dako, Denmark) and counterstaining with Harris's hematoxylin.

\section{Real-time quantitative PCR analysis ( $R T-q P C R)$}

Total RNA was extracted from rat liver and adipose tissue using an RNeasy Mini Kit (Qiagen, France). $500 \mathrm{ng}$ of total RNA was reverse-transcribed using a High Capacity Reverse Transcription Kit (Life Technologies, Forrest City, CA) and RT-qPCR was performed (viiA7, Life Technologies, Forrest City, CA) using EvaGreen qPCR Mix (Solis BioDyne, Estonia). Lipasin expression in the liver and WAT was determined by RT-qPCR using specific primers (NM_001271710.1) Forward: GGAGATTCAGGCAGAAGAGGAC, Reverse: GTGAGAGCCCACAAGAGGTG, product size $213 \mathrm{bp}$;) and normalized to B2m (NM_012512.2) Forward: CCATTCAGAAAACTCCCCAAATTC, 
Reverse: GGCTCCTTCAGAGTGACGTG, product size $271 \mathrm{bp}$ ) and Cyc1 (NM_001277194.1) Forward: GGGACTCAAGATGTTGTTGATG, Reverse: GTTCCTGGTCTGCTGGAGAGC, product size: $172 \mathrm{bp})$. Calculations were based on the comparative cycle threshold $\mathrm{Ct}$ method $\left(2^{-\Delta \Delta \mathrm{Ct}}\right)$, the group of 6 weeks old Wistar rats was taken as the calibrator (Livak and Schmittgen et al. 2001).

\section{Statistical analysis}

Data are presented as a mean $\pm \mathrm{SD}$ of multiple determinations. Statistical significance of the differences among groups was tested using one-way ANOVA with Bonferroni correction for multiple comparisons. Differences were considered statistically significant at the level of $p<0.05$. The correlation between adiposity and lipasin expression in adipose tissue was evaluated using Pearson's correlation coefficient.

\section{Results}

Metabolic characterization of Goto-Kakizaki and Wistar rats

GK rats were growth-retarded throughout the entire experiment as compared to Wistar rats (Fig. 1A). Adiposity steadily increased in Wistar rats, but it remained unchanged in GK rats (Fig. 1A). Triacylglycerols accumulated in the liver of Wistar rats along with age (more than four-fold over 52 weeks), but the lipid content did not increase over the same time period in the liver of GK rats (Fig. 1B). Serum triglycerides remained within the range $0.8-1.6 \mathrm{mmol} / \mathrm{l}$ and did not significantly differ between the two strains (data not shown). Blood glucose concentration steadily rose over 52 weeks in GK rats, reaching overt hyperglycemia already by the age of 20 weeks (Fig. 1C). In Wistar rats it remained within the normal range throughout the whole year (Fig. 1C). Glucose tolerance and its two critical components, insulin sensitivity and insulin secretion, were evaluated in vivo and in vitro. GK rats were glucose-intolerant to a high degree already at the age of 6 weeks and they remained so throughout the study (Fig. 2A). Wistar rats became glucose-intolerant to a mild degree only at the age of 52 weeks (Fig. 2A). Insulin-sensitivity of peripheral tissues was assessed in vitro for muscle and WAT. The ability of insulin to stimulate incorporation of glucose into glycogen (muscle) or into neutral lipids (WAT) did not differ between the two strains at the age of 6 weeks and it dropped by the age of 20 weeks in both strains (Figs 2B and 2C). However, the decrease of insulin-sensitivity on both tissues was three-fold deeper in GK than in Wistar rats. In GK rats, serum insulin rose two-fold by the age of 20 weeks, but its concentration gradually declined below the original level (Fig. 3A). In Wistar rats, insulin increased three-fold by the age of 20 weeks and remained relatively stable for 52 weeks (Fig. 3A). In vitro, glucosestimulated insulin secretion by isolated islets rose by the age of 20 weeks in both strains. While it gradually declined in GK rats, it remained stable in Wistar rats (Fig. 3B). Histological examination showed morphological distortion and diminution of the GK islets, including stellar shaped islets, by 20 weeks of age which progressed further on. Proliferation activity visualized in pancreatic islets by immunohistochemical presence of "proliferating cell nuclear antigen" (PCNA) responsible for DNA replication and repair was lower in GK rats as compared to age-matched Wistar controls (Fig. 4).
A

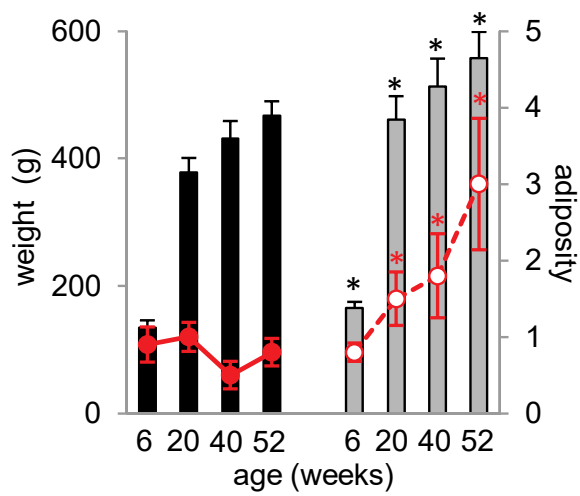

B

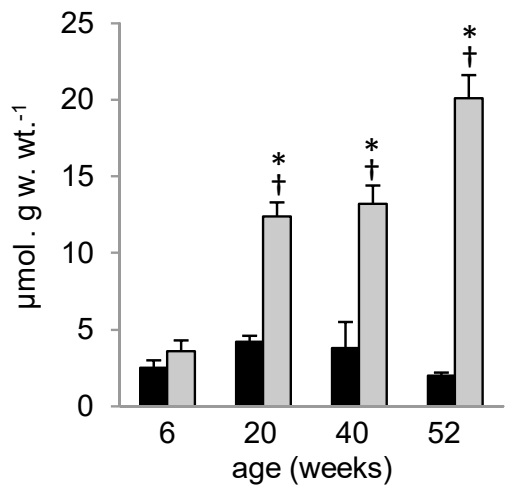

C

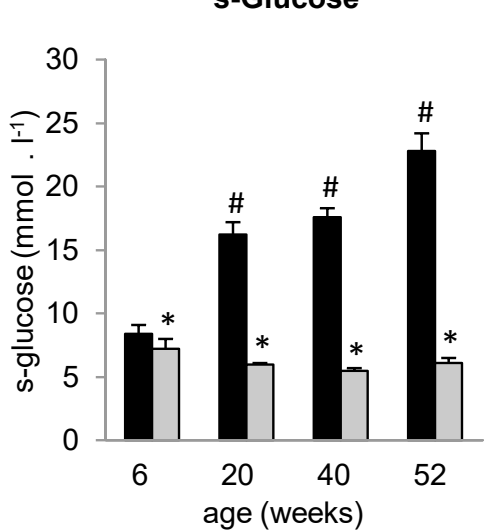

Fig. 1. Characterization of GK model and the age-matched Wistar controls. A) weight and adiposity of GK/Tac a Wistar rats during the experiment. Black bars - GK rats, grey bars - Wistar rats, red lines indicate adiposity expressed as the ratio of epididymal fat pads weight per $100 \mathrm{~g}$ body weight; B) liver triacylglycerol content; C) blood glucose (fed). Statistical significances were evaluated using one way ANOVA with Bonferroni correction: * $p<0.05$ Wistar vs. Goto, \# $p<0.05$ GK vs. 6 -week-old GK, $\dagger p<0.05$ Wistar vs. 6-week-old Wistar. 
A

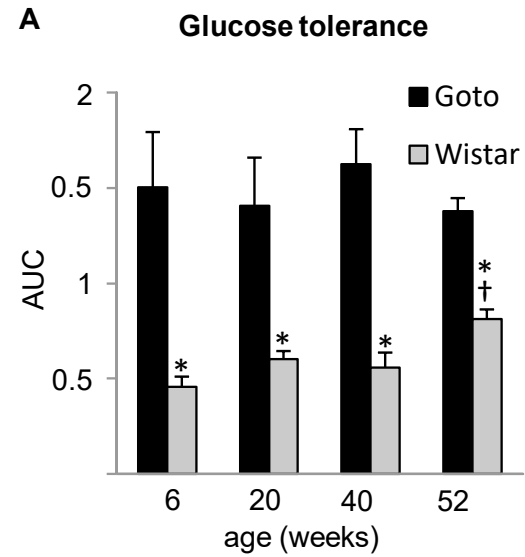

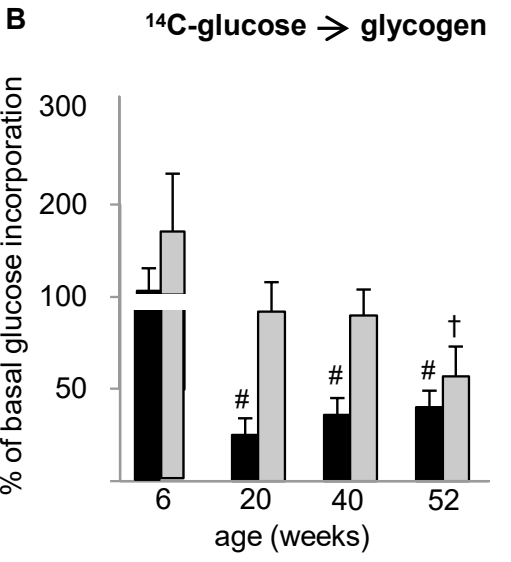

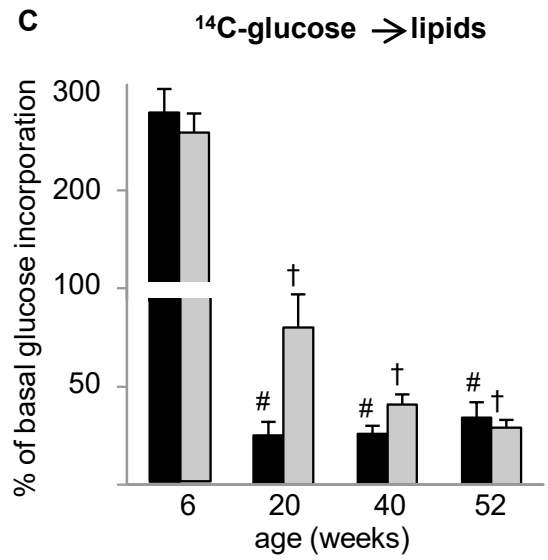

Fig. 2. Glucose tolerance and peripheral tissue insulin sensitivity in GK model and the age-matched Wistar controls. A) glucose tolerance measured as IPGTT ( 6 weeks) or IVGTT (20, 40 and 52 weeks), data are expressed as area under curve (AUC) in mol glucose per 60 and $120 \mathrm{~min}$, resp.; B) effect of insulin on the incorporation of glucose into glycogen ( $\mu \mathrm{mol}$ glucose. $\mathrm{g} \mathrm{w} \cdot \mathrm{wt}^{-1} .60 \mathrm{~min}^{-1}$ ) in $\mathrm{m}$. soleus in vitro expressed as the insulin-stimulated increase over the basal incorporation (\%); C) effect of insulin on the incorporation of glucose into lipids ( $\mu \mathrm{mol}$ glucose. $\mathrm{g} \mathrm{w} \cdot \mathrm{wt}^{-1} .60 \mathrm{~min}^{-1}$ ) in epididymal adipose tissue in vitro expressed as the insulin-stimulated increase over the basal incorporation (\%). Statistical significances were evaluated using one way ANOVA with Bonferroni correction: * p $<0.05$ Wistar vs. Goto; \# p $<0.05$ GK vs. 6-week-old GK; † p $<0.05$ Wistar vs. 6-week-old Wistar.

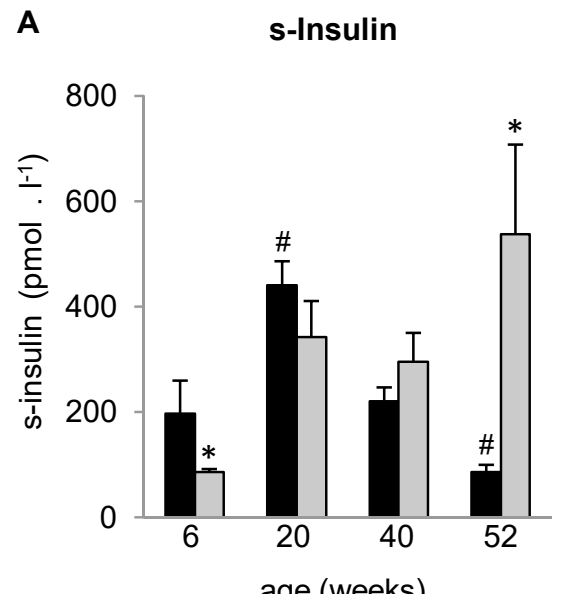

B

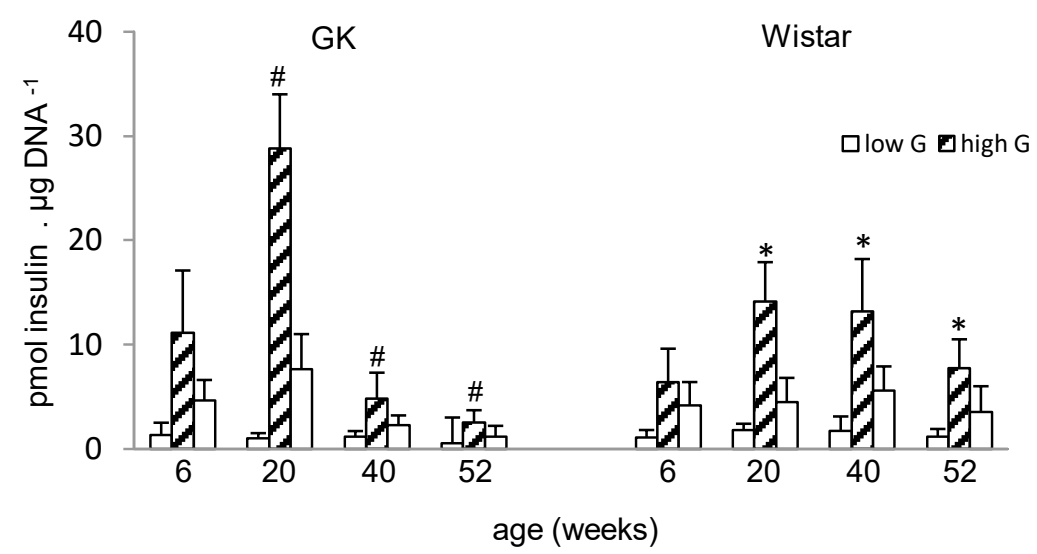

Fig. 3. Fed serum insulin (A) and glucose-stimulated insulin secretion (B) of pancreatic islets in vitro (low $\mathrm{G}=3 \mathrm{mM}$ glucose, high $\mathrm{G}=22 \mathrm{mM}$ glucose). Black bars - GK rats, grey bars - Wistar rats, white bars - low glucose, hatched bars - high glucose. All data are expressed as a mean $\pm S D, n=6-8$. Statistical significances were evaluated using one way ANOVA with Bonferroni correction: * $p<0.05$ Wistar vs. Goto, \# p<0.05 GK vs. 6-week-old GK.

\section{Lipasin expression in liver and WAT}

The expression of lipasin specific mRNA was evaluated at the same time points as the metabolic assessment in the two most important organs. In the liver, the expression of lipasin decreased gradually with age, and did not differ between the strains (Fig. 5A). In WAT, there was also no difference in the expression at the age of 6 weeks between GK and Wistar rats. However, since the age of 20 weeks, the expression gradually declined in the GK rats, while it steadily rose in Wistar rats (Fig. 5B). The lipasin mRNA expression correlated neither with the degree of insulin resistance nor with serum level of triglycerides. The only correlation was found between the lipasin expression in WAT and adiposity $(\mathrm{R}=0.81)$ in Wistar rats (Fig. 5B). This data show that the level of lipasin expression is not related to insulin resistance in GK rats in the two most relevant organs and is differentially expressed in liver and white adipose tissue.

\section{Discussion}

We present here the first metabolic study into the expression of endogenous lipasin in GK and Wistar rats. It produced two unexpected findings. First, our data show in GK rats, that the expression of lipasin in liver and WAT remained unaffected by the presence of severe insulin 
resistance (Figs $5 \mathrm{~A}$ and $5 \mathrm{~B}$ ). Our data contrast with the findings reported in other rodent models of insulin resistance states, e.g. ob/ob mice, $d b / d b$ mice, pregnant mice, and the mice treated with inhibitor of insulin receptor, where an increased levels of lipasin mRNA in liver and WAT or lipasin protein in serum were reported (Yi et al. 2013). One possible caveat in our study is the control animals to which the lipasin expression is compared. Ideally, the same strain without insulin resistance should be used. However, GK rats were insulin resistant already at the age of 6 week, precluding such a control. Wistar rats are an outbred strain from which GK were developed (Portha 2012), so they are genetically similar, but not identical. It is therefore plausible to assume that the two strains differ in yet unknown gene or set of genes, which regulate expression of lipasin in liver and fat. Lipasin is a metabolically regulated protein (Ren et al. 2012, Stephens 2012, Zhang et al. 2014). While our animal were fed ad libitum and sampled at fixed time, the authors of the reports on mice do not provide much information regarding the feeding and sampling.

The data concerning the time course of the onset of insulin resistance and beta cell failure in GK rats are not absolutely coherent throughout the literature. The important factor seems to be the origin of experimental animals, i.e. the breeding colony. Portha et al. (2012) using GK/Par colony demonstrated markedly reduced in vivo secretory beta cell response to glucose together with increased insulin sensitivity in 3 weeks old prediabetic GK/Par rats (Portha et al. 2012, Movassat et al. 2008). Two month old GK/Par rats have significantly decreased insulin-stimulated whole body glucose uptake but peripheral tissue insulin resistance was proved in some but not all tissues and there was no evidence for clear-cut decreased skeletal muscle insulin action (Berthelier et al. 1997). In contrast, Wallis et al. $(2008,2004)$ demonstrated enhanced insulin secretory capacity both in vivo and in vitro in 12 and 24 weeks old animals together with selective insulin resistance in peripheral tissues in animals originating from GK/Ox colony (Wallis et al. 2008, Wallis et al. 2004). Our experimental animals coming from Taconic colony (GK/Tac) exhibit severe glucose intolerance at 6 weeks of age and insulin resistance in WAT and skeletal muscle since the age of 20 weeks. In accordance with Wallis et al. $(2008,2004)$ and in contrast to data reported by Portha et al. (2012) and Ostenson et al. (1993) we found enhanced glucose-stimulated insulin secretion in vitro in 20 weeks old GK/Tac rats that got severely deteriorated between 20 and 40 weeks of age.
Despite the fact of currently identified delta cell hyperplasia (Alan et al. 2015) but in line with previously reported findings (Portha et al. 2010) we did not observed any significant proliferation activity in GK/Tac islets. On the other hand, generally decreased PCNA immunostaining and decrease of proliferative activity in GK islets can be explained just by the increased paracrine secretion of somatostatin from increased number of delta cells (Stewart et al. 1995). However, the data presented in our study does not allow identifying the primary defect leading to beta cells failure in older $\mathrm{GK} / \mathrm{Tac}$ rats but point to the importance of considering the GK origin for the interpretation of the results.

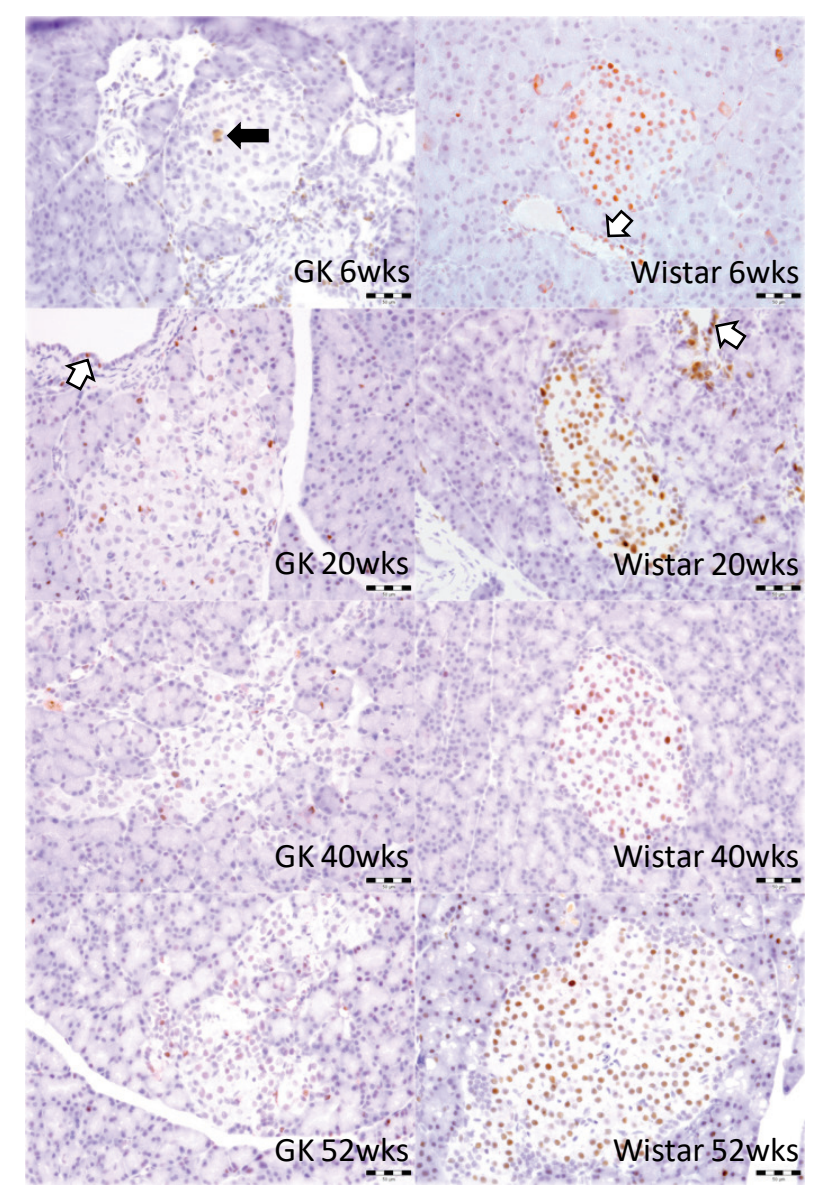

Fig. 4. Evaluation of DNA replication and repair activity visualized by immunohistochemical presence of "proliferating cell nuclear antigen" PCNA. A full range nuclear positivity of PCNA from weak to strong was a dominant observation in Wistar control islet cells at age of week 6 , week 20 , week 40 and week 52 . In age-matched GK animals, absence of PCNA nuclear positivity was a dominant islets finding with only individual observation of weak to medium PCNA-positive nuclei. In week 6 GK sample, a cytoplasmatic positivity of PCNA was observed in presence of mitotic chromatin figure (black arrow). Since week 20, disturbance of islets shape could be observed in GK animals leading up to stellar shape of islets appearing since week 40 . PCNA nuclear positivity of proliferating ductal epithelial cells serves an internal control (white arrows). Original magnification $400 x$. 
A

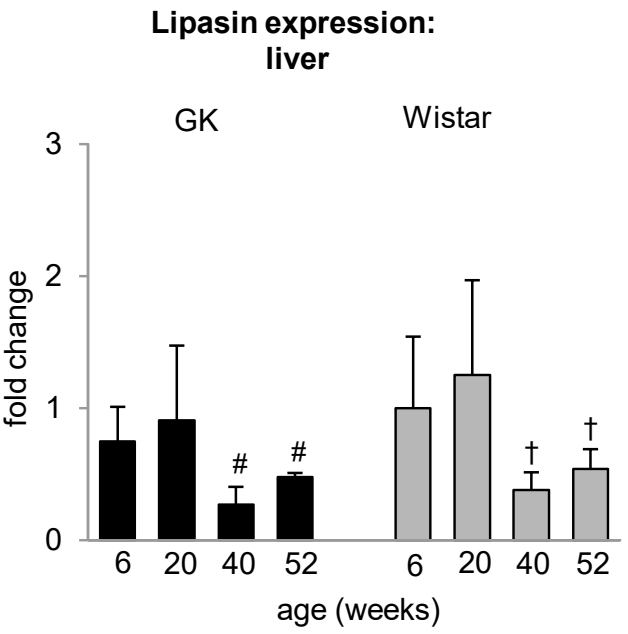

Lipasin expression: WAT

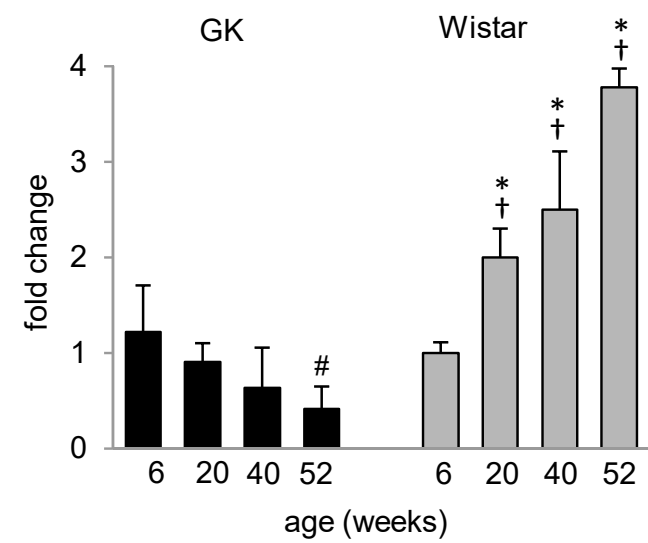

Fig. 5. Lipasin specific mRNA expression in liver (A) and epididymal adipose tissue (B). Data are expressed as fold changes relative to 6 weeks old Wistar rats (mean $\pm S D, n=6-8$ ). Black bars - GK rats, grey bars - Wistar rats. Statistical significances were evaluated using one way ANOVA with Bonferroni correction: $* p<0.05$ Wistar vs. Goto, $\# p<0.05$ GK vs. 6-week-old GK, $+p<0.05$ Wistar vs. 6-week-old Wistar.

The second unexpected finding in Wistar rats was that lipasin is differentially expressed in the liver and WAT. Wistar rats aged 52 weeks developed low degree of insulin resistance, but no association with hepatic lipasin expression was found. On the other hand, adiposity increased three-fold in one year old Wistar rats, which positively correlated with the lipasin mRNA expression in adipose tissue, suggesting a positive feedback mechanism. This finding of differential expression of lipasin has not been reported before in any species. It suggests that lipasin regulation is cell/tissue specific. Indeed it is not yet clear, by which cell type in the liver it is expressed and secreted. The finding that lipasin expression in adipose tissue but not in the liver increases proportionally with the adiposity might also explain the failure of GK rats to respond to insulin resistance with rise of lipasin. GK rat had very small amount of adipose tissue throughout the study. It is possible that a minimum amount of fat is required to mount significant response of lipasin mRNA to insulin resistance.

Some studies in humans associate increased plasma levels of lipasin with insulin resistance and obesity (Yamada et al. 2015, Tokumoto et al. 2015, Chen et al. 2015, Fenzl et al. 2014), while other authors reported the opposite findings (Gomes-Ambrosi et al. 2014). It is difficult to compare our results to human studies, which were all based only on levels of lipasin in serum sampled after overnight fast, which are dependent on antibody-based assays (ELISA or RIA). One explanation of the discrepancies, at least in human studies, provided Fu et al. (2014a) who have shown that most of the circulating lipasin lack the $\mathrm{N}$-terminus and suggested that full-length lipasin protein in serum may undergo proteolytic cleavage, resulting in release of the residual C-terminus. Importantly, some of the commercially available kits use antibodies that recognize the N-terminus, while others recognize the $\mathrm{C}$-terminus. For rats, the information regarding the target sequence is not available.

Our data derived from lipasin expression in WAT are in line with reports linking lipasin to lipid metabolism but not to glucose homeostasis (Zhang et al. 2013, Ren et al. 2012, Fenzl et al. 2014). To our knowledge, the differential expression of lipasin specific mRNA in liver and WAT had not been reported before. It remains to be seen, whether indeed the adipose tissue, not the liver, is primarily responsible for the variation of lipasin blood levels in response to metabolic challenges.

In conclusion, our study demonstrates that hepatic expression of lipasin mRNA is associated neither with a mild age-related insulin resistance (Wistar rats) nor with severe genetically-based insulin resistance (GK rats). In normoglycemic Wistar rats we show that lipasin is differentially expressed in the liver and WAT. In WAT, we found positive correlation between lipasin mRNA expression and adiposity.

\section{Conflict of Interest}

There is no conflict of interest.

\section{Acknowledgements}

This study was supported by grant No. 13-06666 from GA CR and by MH CR - DRO ("Institute for Clinical and Experimental Medicine - IKEM, IN 00023001”). 


\section{References}

ALAN L, OLEJÁR T, CAHOVA M, ZELENKA J, BERKOVA Z, SMETAKOVA M, SAUDEK F, MATEJ R, JEZEK P: Delta cell hyperplasia in adult Goto-Kakizaki (GK/MolTac) diabetic rats. J Diabetes Res 2015: 385395, 2015.

BERKOVA Z, KRIZ J, GIRMAN P, ZACHAROVOVA K, KOBLAS T, DOVOLILOVA E, SAUDEK F: Vitality of pancreatic islets labeled for magnetic resonance imaging with iron particles. Transplant Proc 37: 3496-3498, 2005.

BERTHELIER C, KERGOAT M, PORTHA B: Lack of deterioration of insulin action with aging in the GK rat: a contrasting adaptation as compared with non-diabetic rats. Metabolism 146: 890-896, 1997.

CAHOVA M, VAVRINKOVA H, MESCHISVILLI E, MARKOVA I, KAZDOVA L: The impaired response of non-obese hereditary hypertriglyceridemic rats to glucose load is associated with low glucose storage in energy reserves. Exp Clin Endocrinol Diabetes 112: 549-555, 2004.

CHEN J, CHEN S, HUANG P, MENG XL, CLAYTON S, SHEN JS, GRAYBURN PA: In vivo targeted delivery of ANGPTL8 gene for beta cell regeneration in rats. Diabetologia 58: 1036-1044, 2015.

FENZL A, ITARIU BK, KOSI L, FRITZER-SZEREKES M, KAUTZKY-WILLER A, STULNIG TM, KIEFER FW: Circulating betatrophin correlates with atherogenic lipid profiles but not with glucose and insulin levels in insulin-resistant individuals. Diabetologia 57: 1204-1208, 2014.

FLIER SN, KULKARINI RN, KAHN CR: Evidence for a circulating islet cell growth factor in insulin-resistant states. Proc Natl Acad Sci USA 98: 7475-7480, 2001.

FU Z, ABOU-SAMRA AB, ZHANG R: An explanation for recent discrepancies in levels of human circulating betatrophin. Diabetologia 57: 2232-2234, 2014a.

FU Z, BERHANE F, FITE A, SEYOUM B, ABOU-SAMRA AB, ZHANG R: Elevated circulating lipasin/betatrophin in human type 2 diabetes and obesity. Sci Rep 4: 5013, 2014 b.

GOMES-AMBROSI J, PASCUAL E, CATALAN V, RODRIGUEZ A, RAMIREZ B, SILVY C, GIL MJ, SALVADOR J, FRUHBECK G: Circulating betatrophin concentrations are decreased in human obesity and type 2 diabetes. J Clin Endocrinol Metab 99: E2004-E2009, 2014.

GUSAROVA V, ALEXA CA, NA E, STEVIS PE, XIN Y, BONNER-WEIR S, COHEN JC, HOBBS HH, MURPHY AJ, YANCOPOULOS GD, GROMADA J: ANGPTL8/betatrophin does not control pancreatic beta cell expansion. Cell 159: 691-696, 2014.

KAESTNER KH: Betatrophin-promises fading and lessons learned. Cell metabolism 20: 932-933, 2014.

LEIBOWITZ G, KAISER N, CERASI E: $\beta$-Cell failure in type 2 diabetes. J Diabetes Investig 2: 82-91, 2011.

LIVAK KJ, SCHMITTGEN TD: Analysis of relative gene expression data using real-time quantitative PCR and the 2(-Delta Delta C(T)) Method. Methods 25: 402-408, 2001.

MOVASSAT J, BAILBE D, LUBRANO-BERTHELIER C, PICAREL-BLANCHOT F, BERTIN E, MOUROT J, PORTHA B: Follow-up of GK rats during prediabetes highlights increased insulin action and fat deposition despite low insulin secretion. Am J Physiol Endocrinol Metab 294: E168-E175, 2008.

OSTENSON CG, KHAN A, ABDEL-HALIM SM, GUENIFI A, SUZUKI K, GOTO Y, EFENDIC S: Abnormal insulin secretion and glucose metabolism in pancreatic islets from the spontaneously diabetic GK rat. Diabetologia 36: 3-8, 1993.

PORTHA B, LACRAZ G, CHAVEY A, FIGEAC F, FRADET M, TOURREL-CUZIN C, HOMO-DELARCHE F, GIROIX MH, BAILBE D, GANGNERAU MN, MOVASSAT J: Islet structure and function. Adv Exp Med Biol 654: 479-500, 2010.

PORTHA B, GIROIX MH, TOURREL-CUZIN C, LE-STUNFF H, MOVASSAT J: The GK rat: a prototype for the study of non-overweight type 2 diabetes. Methods Mol Biol 933: 125-159, 2012.

QUAGLIARINI F, WANG Y, KOZLITINA J, GRISHIN NV, HYDE R, BOERWINKLE E, VALENZUELA DM, MURPHY AJ, COHEN JC: Atypical angiopoietin-like protein that regulates ANGPTL3. Proc Natl Acad Sci USA 109: 19751-19756, 2012.

REN G, KIM JY, SMAMS CM: Identification of RIFL, a novel adipocyte-enriched insulin target gene with a role in lipid metabolism. Am J Physiol Endocrinol Metab 303: E334-E351, 2012. 
SEDOVA L, SEDA O, KRENOVA D, KREN V, KAZDOVA L: Isotretinoin and fenofibrate induce adiposity with distinct effect on metabolic profile in a rat model of the insulin resistance syndrome. Int J Obes Relat Metab Disord 28: 719-725, 2004.

STEPHENS JM: RIFL aims to be a new player in lipid metabolism. Am J Physiol Endocrinol Metab 303: E332-E333, 2012.

STEWART GJ, CONNOR JL, LAWSON JA, PREKETES A, KING J, MORRIS DL: Octreotide reduces the kinetic index, proliferating cell nuclear antigen-maximum proliferative index, in patients with colorectal cancer. Cancer 76: 572-578, 1995.

TOKUMOTO S, HAMAMOTO Y, FUJIMOTO K, YAMAGUCHI E, OKAMURA E, HONJO S, IKEDA H, WADA Y, HAMASAKI A: Correlation of circulating betatrophin concentrations with insulin secretion capacity, evaluated by glucagon stimulation tests. Diabet Med 32: 653-656, 2015.

TREBOTIC LK, KLIMEK P, THOMAS A, FENZL A, LEITNER K, SPRINGER S, KIEFER FW, KAUTZKYWILLER A: Circulating betatrophin is strongly increased in pregnancy and gestational diabetes mellitus. PLoS One 10: e0136701, 2015.

WALLIS RH, WALLACE KJ, COLLINS SC, MCATEER M, ARGOUD K, BIHOREAU MT, KAISAKI PJ, GAUGUIER D: Enhanced insulin secretion and cholesterol metabolism in congenic strains of the spontaneously diabetic (type2) Goto Kakizaki rat are controlled by independent genetic loci in rat chromosome 8. Diabetologia 47: 1096-1106, 2004.

WALLIS RH, COLLINS SC, KASAKI PJ, ARGOUD K, WILDER SP, WALLACE KJ, RIA M, KTORZA A, RORSMAN P, BIHOREAU MT, GAUGUIER D: Pathophysiological, genetic and gene expression features of a novel model of cardio-metabolic syndrome. PLoS One 3: e2962, 2008.

YAMADA H, SAITO T, AOKI A, ASANO T, YOSHIDA M, IKOMA A, KUSAKA I, TOYOSHIMA H, KAKEI M, ISHIKAWA SE: Circulating betatrophin is elevated in patients with type 1 and type 2 diabetes. Endocr J 62: 417-421, 2015.

YI P, PARK JS, MELTON DA: Betatrophin: a hormone that controls pancreatic $\beta$ cell proliferation. Cell 153: 747-758, 2013.

YI P, PARK JS, MELTON DA: Perspectives on the activities of ANGPTL8/betatrophin. Cell 159: 467-468, 2014.

ZHANG R, ABOU-SAMRA AB: Emerging roles of Lipasin as a critical lipid regulator. Biochem Biophys Res Commun 432: 401-405, 2013.

ZHANG R, ABOU-SAMRA AB: A dual role of lipasin (betatrophin) in lipid metabolism and glucose homeostasis: consensus and controversy. Cardiovasc Diabetol 13: 1-9, 2014. 